\title{
When Politics Drive Program Innovation
}

\author{
Judith Zamir $^{1}$, Khaled Al-Sayed ${ }^{1}$, Ibrahim Elbadour ${ }^{1}$ \& Saleem Abu Jaber ${ }^{1}$ \\ ${ }^{1}$ Kaye Academic College of Education, Beer Sheva, Israel \\ Correspondence: Judith Zamir, Kaye Academic College of Education, Beer Sheva, Israel. Tel: 972-54-4929974.
}

Received: May 26, 2018

Accepted: June 24, 2018

Online Published: July 2, 2018

doi: $10.20849 /$ jed.v2i 2.412

URL: https://doi.org/10.20849/jed.v2i2.412

\begin{abstract}
This article presents a discussion of the evaluation of an educational intervention introduced by the Ministry of Education in response to social and political pressure. The social protest that started in Israel during the summer of 2011 addressed a variety of social issues, lasted through 2016 and led to the Ministry of Education decision to open a new training programme for teachers. One of the aims of the intervention was to provide an additional adult in classrooms of more than 32 pupils. To meet this goal, the Ministry required third-year student teachers to work at schools co-teaching with the classroom teacher three days a week. Twenty-five institutions of higher learning representing 81 cities and communities responded "yes" to the call for a pilot programme. Using mixed methods, the evaluation of the pilot was attentive to the voices of all participants and revealed the complexity of the programme. The conclusions and suggestions of the evaluation were supposed to feed into a policy decision, but unfortunately did not. Through a presentation of the evaluation of the programme and the issues it raised, the article contributes a significant example of how political constraints prevent institutions from dealing with evaluation conclusions and unintended outcomes of programs.
\end{abstract}

Keywords: political constraints, efficiency, efficacy, dialogical evaluation, Partner Development School, Training Teachers

\section{Background}

\subsection{The Call for Social Change}

During the summer of 2011, Israelis took to the streets to protest economic and social conditions. On September 3, 2011, Ynet, a major Israeli news outlet, wrote, "According to police estimates, 250,000 protesters gathered in Tel Aviv's National Square after marching from the city's Habima Square”. Charlie Bitton, leader of the 1970's Black Panthers movement led the marchers. They expressed dissatisfaction over the high cost of living and chanted "The people demand social justice". On September 4, the Guardian wrote, "Among the issues raised were the cost of housing, transport, childcare, food and fuel; the low salaries paid to many professionals, including doctors and teachers; tax reform; and welfare payments". The government established a committee led by the economist, Professor Manuel Trajtenberg to examine the protesters' demands. The committee's report was presented to Prime Minister Netanyahu on March 2014. The social discontent did not quiet down and, in fact, it exploded again during the summer of 2016. On August 3, 2016, Jerusalem online wrote, "The Forum of Regional Parents Unions organized demonstrations in Tel Aviv on Sunday morning protesting overcrowding in classrooms. This move directly affects tens of thousands of students and it is expected to broaden in the next few days and include schools in the rest of the country. 'Bennett (the Minister of Education) wakes up, education is worth more' the parents and students demonstrating outside the school gates cried". The movement became known as the Sardine Protest.

Following the Sardine Protest in 2016, the Ministry of Education promoted a new programme for training teachers named "Academy in Class" and called on institutions of higher learning to participate in a pilot. Kaye Academic College was one of these institutions.

\subsection{About Kaye Academic College}

Kaye Academic College is the leading academic institution for teacher education and professional development of educators in the south of Israel, serving both the Jewish and Bedouin populations in the Negev area. At present there are 4.000 Jewish and Bedouin students (50\% Jewish and 50\% Bedouin) studying in various college departments. Students earn a B. Ed. degree and teacher certificate, for teaching from kindergarten to high school in a wide range of specializations. The college offers five programmes towards a master's degree in education 
(M. Ed.), and functions as a center for research and furthering professional development of teachers in the field.

Kaye Academic College of Education seeks to prepare teachers who will take the initiative and become leaders in their schools and in their communities, who can function in a multicultural environment and reach out to every one of their pupils. This article presents the work conducted within the Training Programme for Teachers for Elementary Schools in Bedouin Society.

\subsection{Description of the New Programme}

The new programme, called Academy in Class is based on Partner Development School (PDS) models as developed throughout the world over the last 10 years (Million \& Vare, 1997). The programme consists of pairing institutions with schools in which third-year student teachers are assigned to co-teaching situations with a classroom teacher. The student teachers work in the school three days a week in addition to their regular course load at the college. Each student is assigned a pedagogical mentor from the affiliated college or university who mentors the student and the teacher at work at the school.

The Ministry of Education outlined the following aims of the programme:

- Encouraging meaningful learning with the help of a co-teaching team of two adults (a teacher and a student teacher)

- Improving pre-service teacher training

- Building a continuum of teacher' professional development from student teacher, to teacher, to experienced teacher, to trainer of student teachers

(The Ministry of Education-Steering Committee-December 2014)

The Ministry of Education invited universities and colleges of education to present proposals as a condition for entering the programme. Twenty-five academic institutions accepted the programme. The 852 students involved in the programme came from 81 urban and rural communities. The article presents the case of Kaye Academic College's Training Track for Elementary School Teachers in Bedouin schools in the Negev. Academy in Class was introduced as a new programme, which in fact it was not. At the time, a model based on PDS principles was in place with adaptations to the needs of the Bedouin community. The difference between the existing programme and the new one concerned time, three days a week in the school and the starting date in September as opposed to October with the academic year.

The new programme was introduced on the basis of this existing PDS model. Three Bedouin elementary schools participated in the programme. Thirty-three third year students worked in co-teaching pairs with the trainers (classroom teachers) in the class. This framework provided the presence of two adults in the crowded classrooms. Three pedagogical mentors from the college supervised the students and trainers. The mentors conducted two workshops with the students: one at the school and one at the college instead of only one at the college. The trainers received a symbolic payment for their work with the students. The mentors received two additional work hours for participating in the new programme. The staff and the students claimed that the new programme was not as good as the model that had been in place previously. However, because the new programme was presented as a response to the social protests, the Ministry of Education commissioned the National Authority for Measurement and Evaluation in Education to monitor and evaluate the change on a national level. The board of each college appointed its own evaluation unit to evaluate the programme at the college level.

\section{Evaluation Model}

The evaluation team understood that the introduction of the new programme was strongly influenced by political interests. The problematic issue of the political presence in evaluation is supported by the literature. According to Bjornholt and Larsen (2014), it is expected that evaluation focused on performance goals will affect political decisions. Weiss (1993) states it clearly "political considerations intrude the evaluation in three major ways. First, all the programmes the evaluation deals with are the creatures of political decisions. Second, evaluation is undertaken in order to feed into decision-making thus entering the political arena. And third, evaluation itself has a political stance. It makes implicit statements about the nature of programmes and their suitability to their goals (p. 94). Aware of the political and social context of the programme, the evaluation team designed an evaluation model that would give voice to all the groups involved in the programme. In the words of Karlsson (1996), this is the case to address "how to involve claims from unfairly treated groups in evaluation and how to choose which criteria should be used for the selection and judgment of what should be evaluated" (p. 405).

Accordingly, the evaluation model was based on a Transformative Paradigm as described by Mertens (1999). The term "transformative" constitutes an umbrella category, for "emancipatory", "anti-discriminatory", 
"participatory", and "feminist" attitudes toward evaluation. It is a process that intends to listen to all the people who are influenced directly and indirectly by the programme. The term relates to all those evaluators who work on behalf of marginalized groups (Mertens, 1999). The model was based on a dialogical process of evaluation (Greene, 2001), giving voice to a large inclusive list of stakeholders and participants. The data was collected by means of mixed methods. The combination of quantitative and qualitative methods made it possible to form a thick description of the programme. It also afforded the opportunity for all participants to bring their own voices into the analysis. The team conducted open interviews with the pedagogical mentors and school principals, interviews with students along the academic year, a closed questionnaire for all students and focus groups with students. The evaluation process aimed at unveiling intended and unintended outcomes of the intervention.

\section{Findings}

The findings included claims both against and for the programme. Significantly, the first round of data supported claims against the programme, the final round, supported claims for the programme. Therefore, they are summarized below in this order.

\subsection{Claims Against the Programme}

Pedagogical mentors and students expressed their complaints about additional hours and a high degree of stress in the new programme. The pedagogical mentors put it this way, "we work three days a week from 8:00 until 14:00, starting on the 1st of September, and we are remunerated for seven hours per week. This is not fair at all. There is a lot of stress, programming workshops for students and teachers, working with principals, solving students and teachers' problems". "I can't be sure their practicum is better because it lasts three days instead of two".

The students expressed it thus, "There is terrible stress this year. We stay 3 days a week at school till 14:30 and then study at the college till 19:30. Too many tasks at school, staying there all through the morning till 14:30 and then there are also tasks for the college. Nobody takes into consideration the students' needs".

Even the school principals, who enjoyed having the presence of two adults in the classroom felt overloaded: "There is too much work: transportation, following up on absences, regulations and procedures. I expect the student teachers to experience significant work here so I must work very hard to provide the best conditions".

The reason for the extended time was not clear to the participants and a sense of ambiguity influenced everyone's motivation to participate in the programme. The students claimed no one had explained the reasons for the change. They felt "out of control" and even considered "dropping out". Pedagogical mentors were influenced by the students' frustration and found it hard to overcome the difficulties. They claimed that the third day of practicum was unnecessary.

There was a strong feeling of lack of choice and coercion. The students expressed it saying that "nobody asks us what we think or feel about the new programme. Somebody decided and we have no choice". And the pedagogical mentors claimed they couldn't object to the choice of the school, the number of students, or the number of days. "I'm a new pedagogical mentor and I do not have enough hours for a full-time position without the extra hours so, I cannot say no".

Moreover, students and mentors understood that school selection was crucial. While there were schools that were ready to absorb the student-teachers, there were others that were unwelcoming.

\subsection{Claims for the Programme}

Despite their initial opposition to the programme, the mentors placed high expectations on the students. They also saw in the programme an opportunity - "the student can have a meaningful experience". They expected their students "to learn from their trainers and lead Action Research". They wanted them to become much more active learners, "building programmes and implementing them with the pupils". One of the principals expressed it this way, "this programme is a great opportunity for the school. Today we have two teachers in the classroom - the teacher and the student teacher. The students are a big help to the teacher-they initiate new activities at school, and go out with the pupils on excursions, etc." The students also thought it was an opportunity, "It's good to experience real school life".

The findings showed students developed a deep sense of belonging to the school and the teaching profession. In the words of the students, "I feel I belong to the school. This feeling reinforces my motivation to work within the school". "The teachers work together as a group and I am part of it". "Thanks to the class teacher's support I believe in my ability [to teach and manage the class]. He [the mentor] values all my initiatives and I can express myself freely thus feeling confidence in my professional skills". Students felt their work was significant, "We 
have an impact on school-for example on significant learning. My teacher trainer started using mixed methods in teaching and learning during our practicum" (meaning the student has had an influence on the trainer). And other student said, "My teacher trainer uses my methods for teaching".

The mentors viewed belonging and influencing the school as goals of the programme, "I want to have an impact on school. The principal listens to me and I feel committed to the school". "After the first weeks of experience, I felt a 'sense of flow' among the students. They started to come on time, ask questions, raise the issues of the school reality, and speak in the school language school programme, differences among students, optimal challenges' ... and it gave me a feeling of satisfaction and ability, I believed that I was able to cope with the students' objections and make the change from a state of dissent to a state of support for the idea".

The students felt the workshops helped them to develop professional skills, "The workshops at school are different from those we participate in at the college. They are tied to practice at school thus are very practical". Other students claimed that, "the practicum is much more effective than academic courses at the college". "We prefer the school work over theory. During the practicum we met different people practicing different roles and jobs at school that enabled us to understand the overall functions of school better". This attitude was a very problematic finding because the practicum is supposed to be elaborated in the light of theory. It provides a learning space in which to broaden understanding and to build the bridge between theory and practice.

Mentors and students felt the programme gave them freedom and supported their sense of autonomy. In the words of one mentor, "There was freedom to work and I felt I could lead things the way I believe are right: I coordinate and guide two workshops [with the student-teachers]: one on class management, and one based on case studies brought by the students". There was a deep sense of freedom of choice as students expressed it, "This year I taught several lessons in class and the teacher gave me the choice. For example, when to teach (a whole lesson or part of it) and the subject or text I want and the activities I want to convey to pupils and she supported all this, this freedom of choice helped me a lot". The mentor's voices expressed their change of attitude toward the programme, "We started [the year] with difficulties, it was not easy". "Today we have no problems. They understand their responsibility as future teachers. They have internalized the role". In the principal's words, "students led and built learning spaces, scientific spaces, active breaks, they are involved in different study excursions, individual learning for pupils."

The principals cited the impact of the mentors on the school, "the mentors are at school throughout the study day and they are a big help". "We get help from the mentors: their knowledge, guiding the trainee's, professional development, etc."

These findings reveal that from the middle of the year, mentors, school principals and students viewed the programme as an opportunity for personal development. Furthermore, they believed it gave them the opportunity to influence the school as a whole. Most of the students expressed a change in their perception of themselves as professionals, "This is an opportunity for me to really know the school, the study programme, and the whole 'world' there is in the school. My perspective about school has changed. I am a teacher now, not a student".

A short overview of the positive outcomes of the programme reveals that the leading team worked according to the principles laid out by Deci and Ryan (2000). "The need for relatedness is the individual's aspiration to maintain close, safe, and satisfying connections in his/her social environment and feel part of it. The need for competence is the individual's need to experience himself or herself as capable of realizing abilities, plans, and aims, which are not always easy to achieve, and feel a sense of efficacy. The need for autonomy is the need for self-determination, meaning and freedom of choice." (pp. 70-71)

\subsection{Summary of the Findings}

A summary of the claims for and against the programme reveals that in spite of the stressful framework created by the new programme, it succeeded in achieving its goals. Indeed, it enabled the students to feel competent and identify with their new role as teachers, while providing two adults in the classroom for the pupils. The staff and the students tried to overcome the constraints and pressures of the programme. They voiced their complaints from the outset, but the policy makers ignored them and made no adaptations to the programme. However, despite the initial feeling of being exploited, the participants developed a positive attitude. In effect, the positive aspects of the programme were a source of pride and covered up the dissatisfaction with the work conditions and lack of remuneration. The evaluation unveiled the social mechanism that enables such exploitation to take place. Festinger, (1962) puts it in sociological terms explaining the phenomenon of cognitive dissonance and the need to justify one's action. The participants had to justify accepting the conditions of the programme by claiming or exaggerating the benefits. Unfortunately, they used the extra time in the classroom to conclude they did not need educational theories in order to be good teachers. This was a negative unintended outcome that needed to be 
addressed.

According to the findings, the evaluation team recommended certain changes in the programme. Adjusting student's timetables, and remunerating the staff in a fairer way, seemed to be basic. In addition, the evaluation team recommended that the policy makers and the college staff review and relate to the huge impact of the practicum on students, making theory disposable and venerating practicum. No changes have been made to date.

\section{Discussion}

This article presented the evaluation study of an educational intervention introduced by the Ministry of Education as a result of social and political pressure. The call for justice in socio-economic affairs that started in 2011 gave rise to the decision to open a new training programme for teachers trying to give a "relatively cheap" and quick answer to the parents' protest against crowded classrooms. One of the first aims of the programme was to provide one more adult in classrooms populated with more than 32 pupils, thus silencing the "sardine protest". Student teachers from the third year of study had to work at school through their practicum for three days a week in co-teaching with the class teacher. Those involved in the work picked up the gauntlet and did their best. The students felt a positive professional self-image. The mentors, students and principals reported that the programme had a strong positive impact on schools. These two facts present hard evidence in favor of the programme demonstrating its effectiveness in terms of goal achievement (Scriven, 1991). Simultaneously, the evaluation found evidence of too many work hours and a high level of stress, resulting in students almost dropping out of the programme. In addition, the impact of working alongside a teacher in the schools allowed students to think there was no need for learning theory. This conclusion on their part could have detrimental results on the quality of their teaching. It is a serious issue that should be discussed. These issues raise questions about the programme's efficacy. In terms of Scriven (1991) efficiency goes beyond effectiveness: it considers the amount of effort needed to achieve the effectiveness. The fact the evaluation listened to all the voices enabled it to unveil the complexities and recommend certain adjustments to the programme as to be expected in a new programme. However, when the evaluation checked the programme the following year, it found that no changes were made at all, neither during the first year, nor after the evaluation recommendations during the second year. As a result of the extra hours, some students had to continue studying an additional year to complete their credits Changes are needed to improve such an effective programme. Unfortunately, the political and economic domain blocked any chance for change. The evaluation conclusions and recommendations were put aside and the programme was disseminated as it was, as a result of governmental pressure. Paradoxically, the staff collaborates with the expansion as it is, exhibiting their pride for the achievements. According to Bourdieu and Passeron (1977) "in matters of culture, absolute dispossession excludes awareness of being dispossessed" (p. 210). This case is representative of programmes that constitute missed opportunities because of political constraints and raise serious questions about the possibility of influencing policy and programming through active evaluation.

\section{Acknowledgements}

The authors thank the participants in the programme: the mentors, the teachers, the student teachers and the principals in each school.

\section{References}

Bjornholt, B., \& Larsen, F. (2014). The politics of performance measurement: evaluation use as mediator for politics. Evaluation, 20(4), 400-411. https://doi.org/10.1177/1356389014551485

Bourdieu, P., \& Passeron, JC. (1977). Reproduction in Education, Society and Culture. London: Sage.

Deci, E., \& Ryan, R. (2000). Self-determination theory and the facilitation of intrinsic motivation, social $\begin{array}{llll}\text { development, and well-being. } & \text { American }\end{array}$ https://doi.org/10.1037/0003-066X.55.1.68

Festinger, L. (1962). A Theory of Cognitive Dissonance. California: Stanford University Press.

Fetterman, D. (2001). Foundations of Empowerment Evaluation. London: Sage.

Greene, J. (2001). Dialogue in evaluation. a relational perspective. Evaluation, 7(2), 181-187. https://doi.org/10.1177/135638900100700203

Karlsson, O. (1996). A critical dialogue in evaluation- how can the interaction between evaluation and politics be tackled? Evaluation, 2(4), 405-416. https://doi.org/10.1177/135638909600200404

Mertens, D. (1999). Inclusive evaluation: implications of transformative theory for evaluation. American Journal of Evaluation, 20(1), 1-14. https://doi.org/10.1177/109821409902000102 
Million, S. K., \& Vare, J. W. (1997). The collaborative school: a proposal for authentic partnership in a professional development school. The Phi Delta Kappan, 78(9), 710-713.

Scriven, M. (1991). Evaluation Thesaurus (4th ed.). Sage: California.

Weiss, C. (1993). Where politics and evaluation research meet. Evaluation Practice, 14(1), 93-106. https://doi.org/10.1016/0886-1633(93)90046-R

Zamir, J., \& Abu Jaber, S. (2015). Promoting social justice through a new teacher training programme for the Bedouin population in the Negev, an evaluation case study. In Rosenstein B., \& Desevilya H. (Eds), New Directions for Evaluation, 146, 71-78. https://doi.org/10.1002/ev.20121

\section{Copyrights}

Copyright for this article is retained by the author(s), with first publication rights granted to the journal.

This is an open-access article distributed under the terms and conditions of the Creative Commons Attribution license (http://creativecommons.org/licenses/by/4.0/). 